\title{
Smart and sustainable cities in the Mediterranean region: The contribution of short supply chains of food
}

\author{
Dos-Santos, M.J.P.L ${ }^{1,2}$, Baptista, N. ${ }^{1,3}$., Machado-Santos, C. ${ }^{4}$ \\ ${ }^{1}$ Escola Superior de Comunicação Social, Instituto Politécnico de Lisboa, Campus de Benfica do IPL, 1549-014 Lisboa, \\ Portugal. \\ ${ }^{2} I U L-$ ISCTE-DINAAMIA'CET, Lisboa, Portugal. \\ ${ }^{3}$ NECE-Universidade da Beira Interior. Convento de Sto. António. 6201-001 Covilhã. Portugal. \\ ${ }^{4}$ UTAD - Quinta de Prados 5000-801 Vila Real, Portugal.
}

Corresponding author: Maria José Palma Lampreia Dos-Santos, Ph.D. tel.: +351 21711 9000, email: msantos@escs.ipl.pt

\begin{abstract}
The cities around the world in general, and in the Mediterranean area in particular, are facing tremendous challenges at the environmental, social, economic, and institutional levels, due to the urbanization trend, environmental climatic changes and challenges due to the ongoing COVID-19 pandemic. Therefore, cities need to be sustainable and smart in the future. An economically important and innovative sector in urban areas is food security. Nowadays, most of the literature explores the concept of smart cities from the point of view of information and communications technology, indeed, the connection with the sustainability aspects of the food supply chain and the ways to operationalize that, remains unsolved. This paper tries to overcome this gap in the literature. The main aim is to analyze the contribution of the short supply chain of food in terms of sustainability in smart cities, regarding current urban trends in cities in general and in Mediterranean areas in particular. The methodology was based on a literature review and includes quantitative and qualitative analysis. The results confirm the existence of positive impacts in the short supply chains of food in urban areas in terms of sustainability. Despite the existence of a considerable number of papers about smart cities and ICT-related topics, the benefits from society of short supply chains of food, and the linkage among the topics and subjects, remain unreferred to or with a limited knowledge exchange.

The conclusions of this paper will be helpful for public decision makers to implement policies in order to promote the sustainability of Mediterranean cities.
\end{abstract}

Keywords - short supply chains of food, sustainability, smart cities, COVID-19, Mediterranean

\section{INTRODUCTION}

Nowadays, the world in general and the cities in particular face tremendous environmental, social, economic, and institutional challenges (Masik et al., 2021; Dos-Santos and Ahmad, 2020). These challenges are currently being exacerbated due to the increasing trend of urbanization of the cities (Dos-Santos, 2016) and the new challenge of living through a convergence of crises (Broo et al., 2021). That was exacerbated by the ongoing coronavirus disease 19 (COVID19) caused by the SARSCoV-2 virus, which was first identified in December 2019 in the Chinese city of Wuhan, and was declared a global pandemic by the World Health Organization (WHO) on March 11, 2020 (Nakamura and Managi, 2020). Since then, the pandemic has rapidly spread beyond China to almost every country on the globe. COVID19 has affected millions of people, with several thousands of deaths in all states and territories around the world (Saadat et al. 2020). Governments worldwide have increasingly undertaken a containment strategy to control the outbreak, relying on widening social and intergovernmental measures at the national and international levels. 
Currently, in 2021, as the ongoing COVID-19 global pandemic spreads across the world, contemporary cities have acquired a new, pivotal role in strategic sustainable development (Bibri, \& Krogstie, 2019; Maaroof, 2015). Therefore, they have gained a central position in the operationalization of the referred Sustainable Development Goals (SDGs), in particular, the Sustainable Development Goal 11 (SGD 11) of the United Nations (UN)' 2030 Agenda, which seeks to make cities more sustainable, resilient, inclusive, and safe (Bibri, \& Krogstie, 2019; Maaroof, 2015). However, according to Miller et al., (2020) over $90 \%$ of COVID-19 cases are in urban areas. This creates per se the biggest challenge, exacerbating the previous urban challenges, because more than half of the world's population is living in urban areas with an increasing trend (Dos-Santos, 2016).

The path of smart cities has a huge development of the literature. The new challenges that cities are facing due to the SDGs of the UN have also created an opportunity for scholars. Urban agriculture and short supply chains of food (SSCFs) acquired in the last decades an increasing importance. However, except for the preliminary work done by Dos Santos (2016), the connection and the promotion of sustainable and smart cities by SSCFs remain unexplored. This paper attempts to overcome this gap in the literature. The main aim is to analyze the contribution of short food supply chains to promote smart and sustainable cities.

\section{The path to smart and sustainable cities}

The UN adopted the New Urban Agenda at the UN Conference on Housing and Sustainable Urban Development in Quito, Ecuador, on 20 October 2016. This was structured by means of an extensive list of institutional recommendations on how to transform urban environments into sustainable entities, from a cultural, socio-economic, and environmental point of view (Kummitha, 2020). Among these recommendations, the UN suggested that expediting sustainable transitions in urban contexts requires adopting a smart-city approach, triggering the input that digital technologies can offer into solving urban challenges and improving the sustainability of urban service provision (Mora and \& Deakin 2019; Schiavone et al., 2020).

Although social influence is claimed to be a deterministic factor in the adoption of technology (Fulk et al., 1987; Kummitha, 2020), hardly any research in urban studies has explored how social influence allows cities to adopt technologies. The literature largely focuses on the general adoption of smart technologies, and largely neglects the social components, namely, the influence from urban communities.

\section{Sustainable development applied to smart and sustainable cities}

The literature traditionally classifies sustainable development based on the social, economic, and environmental components. Furthermore, Dos-Santos and Ahmad (2020) include a new component in sustainable development, namely, the institutional framework.

The institutional component of sustainability includes, according to Dos-Santos and Ahmad (2020), the macroeconomic conditions and public policies to support sustainability, and it is directly related to the SDGs and their respective targets.

At the environmental level, climate change has aggravated serious negative impacts in our societies at all levels. In 2018, the Intergovernmental Panel on Climate Change (IPCC) report highlighted the need for rapid and drastic action on climate change by 2030 , to prevent the disastrous effects of a world warmed by more than $1.5^{\circ} \mathrm{C}$ above pre-industrial levels. This raises the urgency of achieving the UN's SDGs adopted by Member States in 2015. Even with rapid decarbonization, the report warned that it would likely not be sufficient to address the intertwined problems of poverty, mass migration, politics, and ecological collapse that the SDGs seek to address.

Indeed, the Mediterranean Experts on Climate and Environmental Change (MedECC, 2020) reinforce these concerns. According to these authors, annual mean temperatures on land and sea across the Mediterranean Basin are $1.5^{\circ} \mathrm{C}$ higher than during pre-industrial times. MedECC (2020) projections include two scenarios. The first will forecast an increase of 3.8 to $6.5^{\circ} \mathrm{C}$ for a high greenhouse gas concentration until 2100 . The second scenario forecasts an increase in temperature from 0.5 to $2.0^{\circ} \mathrm{C}$. This last scenario is compatible with the long-term goal of the UNFCCC Paris Agreement, to keep the global temperature well below $+2{ }^{\circ} \mathrm{C}$ above the pre-industrial level (RCP2.6).

On the other hand, the MedECC (2020) also indicates that Mediterranean cities are growing due to increasing population and socio-economic change, notably on the coasts. Due to increasing heat stress, the planning and management of cities around the Mediterranean and the world will need to focus more on human health and resilience to environmental change. Impacts of climate change on urban areas are expected to be disproportionally high due to a concentration of population and assets - especially in high-risk prone areas - in combination with hazard-amplifying conditions (e.g., increased run-off resulting from soil sealing, or urban heat island effects).

\section{At the social level}

According to Kummitha (2020), understanding the local social and cultural context is a precondition for attaining technological affordance. This author highlights that social problems represent social reality and offer necessary cognitive frames for technologies to be invented. However, affordance can be difficult to achieve when technologies are forced into smart cities. As social context sets the platform for technological affordance, the effectiveness of smart city technologies is difficult to ascertain (Kummitha, 2020). Although social influence is claimed to be a deterministic 
factor in technology adoption (Fulk et al., 1987; Kummitha, 2020), hardly any urban studies research has explored how social influence allows cities to adopt particular technologies.

The literature largely focuses on the general adoption of smart technologies, and largely neglects the social components, namely, the influence from urban communities and their adoption process of innovation. Indeed, the need to address complex social problems and sustainable change in the face of complex and wicked societal ills, such as the ones resulting from the ongoing coronavirus pandemic, known as COVID19 , emphasize the importance of the social urban problems.

\section{At the economic level}

At the economic level, cities around the world and in Europe present different grades of development and levels of urbanization. Usually, the standard human welfare indicator used is Gross Domestic Product (GDP), and GDP per person among developing and developed countries. This indicator has long been criticized for being overly simplistic and misleading (Lomborg, 2020). According to the Organisation for Economic Co-operation and Development (OECD)(OECD, 2017), GDP was not designed to provide a proxy for both economic and general welfare and presents limitations (Stiglitz et al., 2018; Lomborg, 2020). The problem is that most suggestions for the replacement of GDP as a measure include a dizzying array of indicators, from the UN's 169 SDG targets (UN, 2015) to the 50 well-being indicators in OECD's own How's Life (OECD, 2017; Lomborg, 2020).

\section{At the institutional level}

The world in general and cities in particular present different levels of development (Martinez et al., 2008). This evidence is also present in Mediterranean cities, depending on the location, the continent, and the respective level of development (Dos-Santos et al., 2020). These different levels of development across these cities imply, in general, different levels of policies to support development, as well as different levels to support, invest in and promote sustainability across the countries in general and cities in particular.

\section{Climate change impacts at urban areas in Mediterranean} cities

The 1st MedECC Assessment Report (MedECC, 2020) for the Mediterranean region analyzes future projections of climate and environmental change for the EuroMediterranean region and reveals a high sensitivity to climate change and extreme weather events and its consequences. The expected and inherent negative impacts from climate change are various and with different intensities depending on the areas where they occur (urban, rural, and peri-urban). Mediterranean urban areas have shown spatial heterogeneity in increases, intensity, frequency, and duration of heat waves. Major increases in high-temperature extremes are expected across the Mediterranean region (Kelebek et al., 2021) including hot days $\left(\operatorname{Tmax}>30^{\circ} \mathrm{C}\right.$ ) and tropical nights (Tmin $>20^{\circ} \mathrm{C}$ ) (Molina et al., 2020). Larger increases in intensity and duration are projected for southern Europe, where heat wave days are projected to increase 20 -fold by 2100 (Perkins, 2015). Other projections over the Mediterranean include dramatic increases in the frequency of hot temperature extremes and heat stress by the end of the 21st century (MedECC, 2020). Cities in southern Europe are expected to face longer heat waves (Guerreiro et al., 2018), thus increasing their vulnerability to climate impacts and the need for costly mitigation measures.

The Mediterranean Basin is experiencing major changes in environmental conditions, which can introduce new challenges to the resilience of its natural and human systems (Vafeidis et al., 2021). Current risks to the human population, economies, and ecosystems will increase due to changes in the patterns of droughts, wildfires, soil degradation, desertification, sea-level rise, heat waves and river flooding, and other pressures, potentially leading to greater impacts. These impacts can be further worsened by the occurrence of compound and cumulative events, which can seriously challenge the adaptive capacity and resilience of biophysical and human subsystems. Coping with these risks, adapting to change, and increasing the resilience of Mediterranean systems will be essential for ensuring sustainable development in the region (Vafeidis et al., 2021).

The major changes in environmental conditions will affect, according to the literature, agricultural production in Mediterranean areas and across the world, implying new schemes of distribution in urban areas. Furthermore, policy measures directed at reducing greenhouse gas emissions will continue to strengthen, and companies across the board - not just those with significant emissions-will face increasing pressure to reduce these emissions (European Commission, 2021). The European Green Deal (EGD) establishes the objective of becoming climate neutral in 2050 in a manner that contributes to the European economy, growth, and jobs. This objective requires a greenhouse emissions reduction of $55 \%$ by 2030 , as confirmed by the European Council in December 2020.

\section{The role of smart cities on sustainable development}

Contemporary cities have a pivotal role in strategic sustainable development; therefore, they have gained a central position in operationalizing this notion and applying this discourse. This is clearly reflected in the SGD 11 of the United Nations' 2030 Agenda, which seeks to make cities more sustainable, resilient, inclusive, and safe (Bibri, \& Krogstie, 2019; Maaroof, 2015).

We are living through a convergence of crises (Broo et al., 2021). From the application of sustainability theory and technological change to smart cities, the concept has been in use since the early 1990s (Broo et al., 2021). However, it has gained wide international importance in the last decade due to the increasing urbanization the world is facing, targeting "smartness" as a social, economic, environmental, and urban 
governance goal (Masik et al., 2021) that will improve the quality of life in urban areas.

Moreover, the world is currently facing a COVID-19 pandemic, which creates new challenges for all of society in general and for the cities and short supply chains in particular. This paper attempts to overcome this gap in the literature.

\section{LITERATURE REVIEW}

\section{Main challenges across the Mediterranean cities}

Two out of three people are already living in the urban areas of Mediterranean countries (MC) which is higher than the global average. The United Nations Human Settlements Programme predicts that by around 2050, the urban population will grow to around 170 million in the countries on the northern shore (140 million in 2005) and to over 300 million to the south and east where the population was 151 million in 2005 (United Nations, 2004); Dos-Santos et al., 2020).

The literature presented several projected negative impacts of climate change on economic growth in MC (MedECC, 2020; Dos-Santos et al., 2020), which will have several negative effects mainly in Mediterranean coastal cities. Most of the MC, such as Italy, Spain, Portugal, Greece, and Malta, among other MC, have coastal cities with their economic activities strongly depending on tourism or agricultural and fishing activities. According to Jacob et al., (2014), winters would become milder while summers become warmer and longer.

International political and economic organizations have become aware that high and volatile food prices and deregulated markets put food security at risk and seriously affect global economic, social, and political stability (Koning and Mol, 2009). The financial crisis of 2007 in the USA affected MC in 2008 and has led to instability in agricultural markets and a rise in the prices of these goods (Dos-Santos et al., 2020).

These facts point out the need for investments in adaptive infrastructure in the coming decades, not just in the agriculture and tourism industry sectors, but also in urban areas. Research and development might reduce the cost of adaptation (Tröltzsch and Frelih-Larsen, 2012).

The variants of sustainable urban growth (smart cities, green cities, resilient cities, low carbon cities, sustainable cities) have brought renewed opportunities to create pathways for sustainable urban development (Dos-Santos and Baptista, 2021; Rodriguez et al. 2018).

Therefore, progress can be made by focusing on key opportunities that create precedents for transformative and sustainable urban development in Mediterranean cities. One of the most important aspects in smart cities is the food supply chains.

\section{MATERIALS AND METHODS}

Information and data are from three sources: (i) a literature review coupled with a bibliometric analysis, (ii) preliminary data and insights from a case study developed within the project SDGsConsum (Dos-Santos et al., 2021), and (iii) the results from similar projects developed in Europe, and focused on promoting SFSCs, including the projects COST FA 1503, SMARTCHAIN, and FAO, UN, which are summarized in Baptista and Dos-Santos, (2021).

For the literature review, relevant academic articles were searched on the databases SCOPUS and/or ISI Web of Science (WoS) and Web of Knowledge (WoK) using the combination of keywords "smart cities"; "short food supply chain"; "alternative food network"; "local food"”; "sustainab*"; "economy"; "social"; "environment"; "triple bottom line"; combining these terms with the Boolean conjunctions "OR" and "AND". The search focused on fulltext scientific papers published from 1986 to 2021 and excluded scientific papers, chapters of books, and/or abstracts from conferences not written in English. This phase led to the identification of 2100 articles (after eliminating duplicates) from social sciences to technology, economics and econometrics, business and management, and agricultural sciences.

Second, based on the initial reading of the abstracts and conclusions of the selected papers, articles not related to the topic under investigation were excluded, resulting in 240 articles for deep analysis. Third, to ensure that the most relevant literature was analyzed, a snowball technique was applied, by which backward and forward searches were conducted according to Vom Scheidt et al., (2020) to include other papers cited by the sampled articles relevant to the present research, resulting in a final sample of 254 articles. The quantitative bibliometric analysis on these papers was performed using the VOSviewer software, which is based on well-established Data Analytics Tools. The qualitative analysis of selected articles and case studies was based on content and thematic analysis and involved the following main phases: (i) generating initial codes; (ii) code testing; (iii) coding; (iv) searching for relevant themes; (v) reformation of themes; (vi) defining and naming the final themes; and (vii) final reporting.

\section{RESULTS AND DISCUSSION}

The results confirm an increasing trend of publication mainly in the last years covering the topics "smart-cities"; "sustainability," and SDGs related to the environmental consequences in cities. Most of the papers cover the scientific area of "business and management" (about 24\%) and "agricultural sciences" (23\%); Information and Communication Technologies (ICT) (34\%), and "environmental sciences" (mixed). Among the MC, most of the scientific papers come from Italy (68\%), among other MC (Table 1). 
Table 1. Percentage of papers retrieved by scientific areas in Europe

\begin{tabular}{|l|l|l|}
\hline Scientific areas (\%) & Percentage of papers (\%) & $\begin{array}{l}\text { Major regional area of research } \\
(\mathbf{\%})\end{array}$ \\
\hline Business and management & 23,7 & European countries mixed \\
\hline Agricultural sciences & 22,8 & $\begin{array}{l}\text { Italy (14,8\%); Spain, Germany, and } \\
\text { Portugal (mixed) }\end{array}$ \\
\hline ICT & 34 & $\begin{array}{l}\text { United Kingdom (17,9\%) and various } \\
\text { countries mixed }\end{array}$ \\
\hline Environmental sciences & 19,5 & $\begin{array}{l}\text { Quite normal distribution among } \\
\text { European countries }\end{array}$ \\
\hline Total & 100 & \\
\hline
\end{tabular}

Source: Authors' results, 2021

Nevertheless, except for the seminal works from Dos-Santos (2016) and from Dos-Santos and Baptista (2021), the topic smart cities refer, in a majority of cases, mainly to ICT technologies in order for the cities to become smart. On the other hand, the interest from scholars in sustainability neglects, most of the time until now, the food supply chains in urban areas, or else the topic is referred to from the point the view of ICT, Data analysis (mathematical programing; neural network; econometric models; big data analysis). Other papers refer to the country level's importance of SSCFs, but the component of ICT or sustainability remains absent. Although a substantial number of papers from agricultural and environmental sciences discuss the social benefits of urban agriculture, the linkage among the topics and subjects remains unreferred to or with a limited knowledge exchange.

According to the latter source, smart cities and communities focus on the intersection between energy, transport, and ICT, which are also the fields that have received most of the EU's public smart cities-related funding (under the Horizon program "smart cities and communities").

However, based on the preliminary results from the new projects mentioned above, and mainly from the project SDGsConsum (2020), it is possible to anticipate the main contributions of short supply chains of food on smart cities, in terms of sustainability (economic, social, environmental, and institutional), which are presented in Table 2 (in Appendix).

\section{Contribution of short supply chains of food to sustainable and smart cities}

Although the links between climate change impacts, climate action, and sustainable development are broadly accepted, there has been limited structured investigation in terms of specific SDGs Targets, synergies, and trade-offs (Dos-Santos et al., 2021a).

Table 3 (in Appendix) presents the impacts of SDGs on SSCFs in smart cities. The results confirm that SDGs have several impacts on many targets and goals in various SDGs in smart cities. Moreover, the institutional dimension of
SDGs/sustainability could increase the attention to implement and manage that with public decision makers.

Future research should focus on understanding the impact of different technologies on cities and how the social and cultural contexts in different cities influence the same technology and its level of affordance (Kummitha, 2020).

The results also confirm a huge vulnerability among the cities located in coastal areas of the Mediterranean.

\section{CONCLUSION}

Besides a huge amount of information, data, and results from projects and literature about smart cities, sustainability, and the importance of new forms of agriculture in urban areas, the critical issue about the importance and respective methods and policies to promote SSFCs in smart cities in order to achieve smart and sustainable cities became quite unconnected in general, and in Mediterranean cities in particular.

The results confirm a vast amount of scattered information about the topic, namely, data, results from projects and literature about smart cities, sustainability, and the importance of new forms of agriculture in urban areas. However, the critical issue about the importance and respective methods and policies to promote SSCFs in smart cities in Mediterranean cities remain absent from the literature. This paper makes an attempt to overcome this gap.

Based on the results and discussion are suggestions for policy makers from the European Union to support programs involving the neighboring countries of the Mediterranean on the current Multiannual Financial Framework (2022-2029) with more focus on economic, social, and environmental links between urban, peri-urban, and rural areas by strengthening national and regional development planning in order to promote the SSCFs on the Mediterranean region. On the other hand, it is recommended that a strong investment on coastal programs and actions on cities of the Mediterranean be promoted to overcome and mitigate the negative impacts from climate change. 
Policies that enhance the institutional capacities in Mediterranean cities, including through international cooperation in research and development, must include all components of sustainability in urban and peri-urban areas. The results should be used to advise governments of emerging vulnerabilities in the promotion of short supply chains of food to overcome partial disruptions at the level of international commerce.

From the point of view of research development, the experts from different scientific areas should interact together in order to create a new, adjusted ICT that includes the social perspective of locals and promotes easier adoption by the locals.
The results and conclusion can be used by scholars and public decision makers to achieve the Sustainable Development Goal 17 (SDG17), strengthen the means of implementation, and revitalize the global partnership for sustainable development applied to the smart and sustainable cities in Mediterranean areas.

The paper presents some limitations, namely, this is an exploratory topic not yet consolidated that needs further development from the scientific community. On the other hand, on the information and data, we just consider full papers in English. This could be a limitation because some national case studies/projects in other languages are missing.

\section{APPENDIX}

Table 2. Sustainable impacts of SSCF in smart cities in Mediterranean

\begin{tabular}{|c|c|c|c|}
\hline Economic Impacts & Social impacts & Environmental impacts & Institutional impacts \\
\hline $\begin{array}{l}\text { Reduction of peri- } \\
\text { urban farmers' of MC } \\
\text { economic uncertainties. }\end{array}$ & $\begin{array}{l}\text { Promotion of more } \\
\text { direct relations } \\
\text { between producers } \\
\text { and consumers in } \\
\text { smart cities in MC. }\end{array}$ & $\begin{array}{l}\text { Reduction of resource use } \\
\text { (such as fossil fuel or } \\
\text { packaging). }\end{array}$ & $\begin{array}{l}\text { Promoting a direct increase in the } \\
\text { approval rate of } R \& D \text { projects and } \\
\text { programs and the consequent } \\
\text { competencies in } \begin{array}{l}\text { sectoral } \\
\text { competitiveness. }\end{array}\end{array}$ \\
\hline $\begin{array}{lr}\text { Support } & \text { the } \\
\text { profitability of } & \text { small } \\
\text { and medium urban } \\
\text { farms. }\end{array}$ & $\begin{array}{l}\text { Enhance trust } \\
\text { within the value } \\
\text { chain. }\end{array}$ & $\begin{array}{l}\text { Reduction of food waste } \\
\text { and saving food. }\end{array}$ & $\begin{array}{l}\text { Promoting development, and their } \\
\text { multiplier effect on R\&D. }\end{array}$ \\
\hline $\begin{array}{l}\text { Increase the re- } \\
\text { circulation of urban } \\
\text { community income. }\end{array}$ & $\begin{array}{l}\text { Foster } \\
\text { inclusion. }\end{array}$ & $\begin{array}{l}\text { Promotion of less polluting } \\
\text { production methods (e.g., } \\
\text { organic farming). }\end{array}$ & $\begin{array}{l}\text { Promoting skills development of } \\
\text { staff and researchers. }\end{array}$ \\
\hline $\begin{array}{l}\text { Creation of new jobs in } \\
\text { urban and peri-urban } \\
\text { areas. }\end{array}$ & $\begin{array}{l}\text { Revitalization of } \\
\text { local communities. }\end{array}$ & $\begin{array}{l}\begin{array}{l}\text { Reduction of } \\
\text { emissions }\end{array} \text { and } \\
\text { carbon } \\
\text { footprint. }\end{array}$ & $\begin{array}{l}\text { Increasing the percentage of } \\
\text { R\&D/GDP with a multiplier effect. }\end{array}$ \\
\hline $\begin{array}{l}\text { Decrease of production } \\
\text { costs and market price } \\
\text { for consumers. }\end{array}$ & $\begin{array}{l}\text { Contribution to } \\
\text { urban and peri- } \\
\text { urban development. }\end{array}$ & $\begin{array}{l}\text { Reduction of energy use. } \\
\text { Reduction of food miles. }\end{array}$ & $\begin{array}{l}\text { Increase and promote the } \\
\text { improvement of ICT technologies } \\
\text { and smart cities infrastructures. }\end{array}$ \\
\hline $\begin{array}{l}\text { Improving synergies } \\
\text { with other sectors. }\end{array}$ & $\begin{array}{l}\text { Awaken the sense } \\
\text { of community. }\end{array}$ & $\begin{array}{l}\text { Improving the education } \\
\text { and environment values of } \\
\text { students since the early } \\
\text { years. }\end{array}$ & $\begin{array}{l}\text { Promote the SDGs achievement } \\
\text { and respective targets related to } \\
\text { SDG } 11 \text { and SDG7, among others. }\end{array}$ \\
\hline $\begin{array}{l}\text { Increase of food } \\
\text { production quality and } \\
\text { contribution to } \\
\text { European food safety. }\end{array}$ & $\begin{array}{l}\text { Consumer } \\
\text { empowerment and } \\
\text { better recognition of } \\
\text { producers and food } \\
\text { quality. }\end{array}$ & $\begin{array}{l}\text { Promotion of healthy and } \\
\text { Mediterranean diet, social } \\
\text { and health improvements. }\end{array}$ & $\begin{array}{l}\text { Promotion of IST network } \\
\text { infrastructure and the use of big } \\
\text { data to promote SSCFs. }\end{array}$ \\
\hline
\end{tabular}

Source: Own work based on the results of the Conference conducted within the SDGsCONSUM project and adapted from Dos-Santos and Baptista (2021) and from Jarzębowski et al., (2020). 
Table 3. Impacts of Sustainable Development Goals and targets on SSCF in smart cities in Mediterranean

\begin{tabular}{|c|c|c|}
\hline $\begin{array}{c}\text { Sustainable } \\
\text { Development Goals }\end{array}$ & Target & The role of SGDs and targets on SSCF in smart cities \\
\hline $\begin{array}{l}\text { NO } \\
\text { POVERTY }\end{array}$ & 1.5 & $\begin{array}{l}\text { SSCFs provide a financial resource for entrepreneurs, small producers, disabled people } \\
\text { living in peri-urban areas, reduce the costs of food transportation, provide ecosystems, } \\
\text { improve the living environment and increase property values, ultimately boosting local } \\
\text { green economies. }\end{array}$ \\
\hline 2 ZERO & $\begin{array}{l}2.1 \text { and } \\
2.2\end{array}$ & $\begin{array}{l}\text { SSCFs provide direct food sources and direct markets (e.g., fruits and vegetables, } \\
\text { mushrooms, etc.). }\end{array}$ \\
\hline 2 ZERO & 2.3 & $\begin{array}{l}\text { Increase the income and the agricultural eco-efficiency of small-scale food producers and } \\
\text { family farms, in particular women, family farmers, refugees, and disabled and disadvantaged } \\
\text { people living in peri-urban areas. }\end{array}$ \\
\hline $\begin{array}{l}2 \text { ZERO } \\
\text { HUNGER } \\
\text { S(S) }\end{array}$ & 2.4 & $\begin{array}{l}\text { Urban agriculture and peri-urban agriculture associated with SSCFs ensure sustainable food } \\
\text { production systems and implement resilient agricultural practices that increase productivity } \\
\text { and production, which help maintain ecosystems, that strengthen capacity for adaptation to } \\
\text { climate change, extreme weather, drought, flooding and other disasters and that } \\
\text { progressively improve land and soil quality. }\end{array}$ \\
\hline 11 SUSTANABIE CIIIES & 11.5 & $\begin{array}{l}\text { Reduce the number of people affected and substantially decrease the direct economic losses } \\
\text { relative to global gross domestic product, with a focus on protecting the poor and people in } \\
\text { vulnerable situations caused by disasters, including water-related disasters, by improving } \\
\text { the green and urban areas around the cities and promoting the short supply chains of local } \\
\text { food. }\end{array}$ \\
\hline 11 SUSTANABIECMIIES & 11.6 & $\begin{array}{l}\text { Reduce the adverse per capita environmental impact of cities, paying special attention to } \\
\text { the air quality and waste management. Reduce the } \mathrm{CO}_{2} \text { emissions due to the transport and } \\
\text { storage of food. }\end{array}$ \\
\hline 11 SUSTANABLECTIIES & 11.7 & $\begin{array}{l}\text { Provide access to safe and green areas, in particular for women and children, older persons } \\
\text { and persons with disabilities. } \\
\text { Promote the peri-urban and rural tourism near the cities and reduce the emissions from long } \\
\text { journeys from tourism activities. }\end{array}$ \\
\hline 11 SUSTANABIECIIIES & 11.8 & $\begin{array}{l}\text { Support positive economic, social, and environmental links between urban, per-urban and } \\
\text { rural areas by strengthening national and regional development planning. }\end{array}$ \\
\hline
\end{tabular}

Source: Authors, 2021 adapted from Dos-Santos and Baptista (2021). 


\section{ACKNOWLEDGEMENTS}

The affiliated authors (Dos-Santos, M. and Baptista, N.) from Instituto Politécnico de Lisboa (IPL) and ISCTE-IUL DINÂMIA'CET would like to express her gratitude by the financial support from IDICA 2020 Project SDGsCONSUM, as well as the financial support from DINÂMIA'CETUniversity Institute of Lisbon and NECE from Universidade da Beira Interior.

\section{REFERENCES}

Baptista, N. Dos-Santos, M.J.PL., (2021). Towards smart and sustainable cities through short supply chains of food. ECMLG 17th European Conference on Management Leadership and Governance, 8 - 9 November 2021, Valletta, Malta.

https://www.researchgate.net/publication/356110035 Smart and Sustainable_Cities_Through_Short_Supply_Chains_o f Food

Broo, D.G., Lamb, K., Ehwi, R.J., Pärn, E., Koronaki, A., Makri, C. and Zomer, T. (2021). Built Environment of Britain in 2040: Scenarios and Strategies. Sustainable Cities and Society, 65(102645), pp. 1-35.

DOI: $10.1016 /$ j.scs.2020.102645

Bibri, S. E., \& Krogstie, J. (2019). Generating a vision for smart sustainable cities of the future: a scholarly backcasting approach. European Journal of Futures Research, 7(1), 1-20. DOI: $10.1186 / \mathrm{s} 40309-019-0157-0$

Dos-Santos, M.J.PL., Baptista, N. (2021). Towards smart and sustainable cities through short supply chains of food. Editing book by Bezzina, F., Cassar, V., ECMLG 17th European Conference on Management Leadership and Governance. Readable at Google Books (accessed December 9, 2021).

Dos Santos, M., Moncada, S., Elia, A., Grillakis, M. and Hilmi, N. (2020). Chapter 5 Society | Subchapter 5.1 Development. In: Climate and Environmental Change in the Mediterranean Basin-Current Situation and Risks for the Future. First Mediterranean Assessment Report.

https://www.medecc.org/wp-

content/uploads/2020/11/MedECC_MAR1_5_1_Developme nt.pdf

Dos Santos, M. J. P. L. and Ahmad, N. (2020). Sustainability of European agricultural holdings. Journal of the Saudi Society of Agricultural Sciences, 19(5), pp. 358-364.

DOI: $10.1016 /$ j.jssas.2020.04.001

Dos Santos, M. J. P. L. (2016). Smart cities and urban areasAquaponics as innovative urban agriculture. Urban forestry and urban greening, 20, pp. 402-406.

DOI: $\underline{10.1016 / \text { j.ufug.2016.10.004 }}$
Martinez, J., Mboup, G., Sliuzas, R., \& Stein, A. (2008). Trends in urban and slum indicators across developing world cities, 1990-2003. Habitat International, 32(1), 86-108. DOI: $\underline{10.1016 / \text { j.habitatint.2007.08.018 }}$

MedECC - Mediterranean Experts on Climate and Environmental Change (2020). First Mediterranean Assessment Report (MAR1) (2020).

https://www.medecc.org/first-mediterranean-assessmentreport-mar1/

Dos-Santos, M. J. P. L., Baptistal, N. T., \& Nobre, H. (2021). Exploring the Relationship Between Ethical and Sustainable Consumption in Short Supply Chains: A Literature Review. In International Conference on Applied Human Factors and Ergonomics (pp. 197-203). Springer, Cham.

DOI: $10.1007 / 978-3-030-80876-1 \_26$

European Commission (2021). Proposal for a Directive of the European Parliament and of the Council. (access: https://ec.europa.eu/info/sites/default/files/amendmentrenewable-energy-directive-2030-climate-target-withannexes en.pdf, on 01/08/2021)

Fulk, J., Steinfield, C. W., Schmitz, J. and Power, G. (1987). A social information processing model of media use in organizations. Communication research, 14 (5), pp 529-552. DOI: $\underline{10.1177 / 009365087014005005}$

Guerreiro, S. B., Dawson, R. J., Kilsby, C., Lewis, E., \& Ford, A. (2018). Future heat-waves, droughts and floods in 571 European cities. Environmental Research Letters, 13(3), 034009.

DOI: $\underline{10.1088 / 1748-9326 / \text { aaaad3 }}$

Jacob, D., Petersen, J., Eggert,B., Alias, A., Christensen, O.B., Bouwer, M.L., A Braun, A., Colette, A., Déqué, D., Georgievski, G., Georgopoulou, E., A Gobiet, Menut, A., L., Haensler, G. N.A., Hempelmann, N., Jones, C., Keuler, K., Kovats, S., Kröner, N., Kotlarski, S., Kriegsmann, A., Martin, E., Meijgaard, E.V., Moseley, C., Pfeifer, S., Preuschmann, S., Radermacher, S., Radtke, K., Rechid, D., Rounsevell, M., Samuelsson, P., Somot, S., Soussana, J.F., Teichmann, C., Valentini, R., Vautard, R., Weber B., You, P., (2014). EURO-CORDEX: new high-resolution climate change projections for European impact research. Regional environmental change, 14(2), 563-578.

DOI: $10.1007 / \mathrm{s} 10113-013-0499-2$

Jarzębowski, S., Bourlakis, M. and Bezat-Jarzębowska, A. (2020). Short food supply chains (SFSC) as local and sustainable systems. Sustainability, 12(11), pp. 4715.

DOI: $\underline{10.3390 / \mathrm{su} 12114715}$

Lomborg, B. (2020). Welfare in the 21st century: Increasing development, reducing inequality, the impact of climate change, and the cost of climate policies. Technological Forecasting and Social Change, 156 (119981). 
DOI: $10.1016 /$ j.techfore.2020.119981

Kummitha, R.K.R. (2020). Why distance matters: The relatedness between technology development and its appropriation in smart cities. Technological Forecasting and Social Change, 157(120087).

DOI: $10.1016 /$ j.techfore.2020.120087

Koning, N., and Mol, A. P. (2009). Wanted: institutions for balancing global food and energy markets. Food Security, 1(3), 291-303. Kelebek, M. B., Batibeniz, F., \& Önol, B. (2021). Exposure Assessment of Climate Extremes over the Europe-Mediterranean Region. Atmosphere, 12(5), 633.

DOI: $\underline{10.3390 / \text { atmos } 12050633}$

Maaroof, A. (2015). Big data and the 2030 agenda for sustainable development. Report for UN-ESCAP https://www.unescap.org/sites/default/files/1 Big\%20Data\% 202030\%20Agenda stock-taking\%20report 25.01.16.pdf

Masik, G., Sagań, I. and Scott, J.W., (2021). Smart City strategies and new urban development policies in the Polish context. Cities, 108(102970).

DOI: $10.1016 /$ j.cities.2020.102970

Miller, I. F., Becker, A. D., Grenfell, B. T., \& Metcalf, C. J. E. (2020). Disease and healthcare burden of COVID-19 in the United States. Nature Medicine, 26(8), 1212-1217.

DOI: 10.1038/s41591-020-0952-y

Mora, L. and Deakin, M. (2019). Untangling Smart Cities: From Utopian Dreams to Innovation Systems for a Technology-Enabled Urban Sustainability. Elsevier.

Molina, M. O., Sánchez, E., \& Gutiérrez, C. (2020). Future heat waves over the Mediterranean from an Euro-CORDEX regional climate model ensemble. Scientific reports, 10(1), 110 .

DOI: $\underline{10.1038 / \mathrm{s} 41598-020-65663-0}$

Nakamura, H., and Managi, S. (2020). Airport risk of importation and exportation of the COVID-19 pandemic. Transport Policy, 96, 40-47.

DOI: $10.1016 /$ j.tranpol.2020.06.018

OECD (2017). High Level Expert Group on the Measurement of Economic Performance and Social Progress Publishes its Final Reports http://futureofthewelfarestate.org/high-levelexpert-group-on-the-measurement-of-economicperformance-and-social-progress-publishes-its-final-reports/

Perkins, S. E. (2015). A review on the scientific understanding of heatwaves - Their measurement, driving mechanisms, and changes at the global scale. Atmospheric Research, 164, 242-267.

DOI: $\underline{10.1016 / \mathrm{j} . \text { atmosres.2015.05.014 }}$
Rodriguez, R. S., Ürge-Vorsatz, D., \& Barau, A. S. (2018). Sustainable Development Goals and climate change adaptation in cities. Nature Climate Change, 8(3), 181-183. DOI: $10.1038 / \mathrm{s} 41558-018-0098-9$

Saadat, S., Rawtani, D., \& Hussain, C. M. (2020). Environmental perspective of COVID-19. Science of the Total environment, 728, 138870.

DOI: $10.1016 /$ j.scitotenv.2020.138870

SDGsConsum (2020). The Ethical-Sustainable Consumer Behavior Before and After the COVID Pandemic SDGsConsum (IDICA 2020 IPL Project) http://www.sdgsconsum.com/index.html

Schiavone, F., Appio, F.P., Mora, L. and Risitano, M. (2020). The strategic, organizational, and entrepreneurial evolution of smart cities. International Entrepreneurship and Management Journal, 16(4), pp. 1155-1165.

DOI: $10.1007 / \mathrm{s} 11365-020-00696-5$

Stiglitz, J.E., Fitoussi, J.P. and Durand, M., (2018). Beyond GDP: Measuring What Counts for Economic and Social Performance. OECD Publishing, Paris.

Tröltzsch, J., \& Frelih-Larsen, A. (2012). Methodologies for Climate Proofing Investments and Measures under Cohesion and Regional Policy and the Common Agricultural PolicySeventheenth Annual Report. http://resp.1las.ac.cn/C666/handle/2XK7JSWQ/2623

United Nations (2004). Division de la population, et al. World population to 2300. Vol. 236. United Nations Publications, 2004.

https://www.un.org/development/desa/pd/sites/www.un.org. development.desa.pd/files/files/documents/2020/Jan/un 200 2_world_population to 2300.pdf

United Nations (2015). Department of Economic and Social Affairs.Sustainable Development Goals. The 17 Goals. https://sdgs.un.org/goals

Vafeidis, A. T., Abdulla, A. A., Bondeau, A., Brotons, L., Ludwig, R., Portman, M.,... \& Xoplaki, E. (2021). Managing future risks and building socioecological resilience. Climate and Environmental hange in the Mediterranean Basin Current Situation and Risks for the Future, 2021. ffhal03198766

https://hal.archives-ouvertes.fr/hal-03198766/document

Vom Scheidt, F., Medinová, H., Ludwig, N., Richter, B., Staudt, P., and Weinhardt, C. (2020). Data analytics in the electricity sector-A quantitative and qualitative literature review. Energy and AI, 1, 100009.

DOI: $\underline{0.1016 / j . e g y a i .2020 .100009}$ 
(C) 2021 by the author(s). This article is an open access article distributed under the terms and conditions of the Creative Commons Attribution (CC BY) license (http://creativecommons.org/licenses/by/4.0/). 